\title{
PURIFICATION AND CHARACTERIZATION OF LIPASE FROM PSYCHROPHILIC BACTERIA PSEUDOMONAS MANDELII HTB2 FROM BATURA GLACIER, PAKISTAN
}

\author{
SHAHEEN, M. ${ }^{1,2}$ - Ullah, I. ${ }^{1}$ - RAFIQ, M. ${ }^{1,3}$ - MAQSOOD UR REHMAN, M. ${ }^{1}-$ SHAH, A. A. ${ }^{1}-$ \\ HASAN, F. ${ }^{*}$ \\ ${ }^{I}$ Department of Microbiology, Quaid-i-Azam University, Islamabad, Pakistan \\ ${ }^{2}$ Department of Zoology, GC University, Faisalabad, Pakistan \\ ${ }^{3}$ Department of Microbiology, Balochistan University of Information Technology, Engineering \\ and Management Sciences, Quetta, Pakistan \\ *Corresponding author \\ e-mail:farihahasan@yahoo.com \\ (Received 28 $8^{\text {th }}$ Jul 2018; accepted $4^{\text {th }}$ Feb 2019)
}

\begin{abstract}
Lipases are fat splitting enzymes. Psychrotrophic enzymes including lipases possess huge potential for many industries due to their high activity at low temperatures. Lipase produced by the psychrophilic bacteria HTB2 identified as Pseudomonas mandelii, by using different molecular techniques, isolated from Batura glacier, Hunza Valley, Pakistan, was partially purified through acetone precipitation and gel permeation chromatography. During purification studies two types of peaks were observed in spectrophotometric analysis which indicated the presence of two different sizes of lipases produced by Pseudomonas mandelii HTB2. The purified enzyme from $P$. mandelii $\mathrm{HTB} 2$ showed best activity at $45^{\circ} \mathrm{C}$, however, maximum lipase activity was attained at $\mathrm{pH} 10$. It is a unique finding that an enzyme from a psychrophilic bacterium was active at thermophilic range and extreme alkaline condition. This is the first report of purification of lipase from psychrophilic bacteria from Batura glacier, and it holds promise for potential industrial applications.
\end{abstract}

Keywords: enzyme, alkaline, thermophilic range, low temperature, industrial applications

\section{Introduction}

A large part of the earth consists of cold environment and covered by glaciers, oceans, polar and alpine regions, high mountains, deep seas and cold soils. All of these environments are permanently cold but despite the extreme environmental conditions diverse groups of microorganisms colonize this habitat by developing adaptation strategies to survive or to be highly successful like true psychrophiles (Åqvist et al., 2017). In an efficiently adapted organism the metabolic fluxes become comparatively same to those living at moderate temperature which needs suitable reaction rates. As we know, enzymes are mostly involved in catalysis of many metabolic reactions, so the enzymes produced by these organisms are also cold adapted. This is because of their molecular structure that they work efficiently in cold environment (Pulicherla et al., 2011).

Enzymes are basically proteins generated by living organisms and functioning as specialized catalysts for biochemical reactions. Mostly enzymes are produced from bio-based materials by the process of fermentation (Renge et al., 2012; Smaniotto et al., 2014). Mostly, biomass present in different parts of earth, consists of lipids, and lipolytic enzymes have an important role in the breakdown, and transfer and 
mobilization of (water-insoluble) compounds (Ray, 2012). Formerly, it was found that there are many microorganisms that yields chemical that act as biosurfactants and are involved in solubilization of lipids (Pulicherla et al., 2011).

The specific advantages that are provided by enzymes are specificity for substrates, mild conditions and also reduce waste. By choosing the precise enzyme it may be possible to control which products are produced and unwanted side reactions are reduced via enzyme specificity that involve in the waste stream. The increase in the BOD of water in waste stream due to enzyme is negligible (Szilveszter et al., 2009).

Lipases have appeared one of the leading enzyme and captured more interest for last few years because of great range of applications in many industries. Large numbers of lipases have been screened for its involvement in medicines, food, cosmetics and laundry detergents etc. In animal feed industry lipid hydrolyzing enzymes can be used an additive to enhance energy gain from feed in the animal feed industry. The enzyme supplement is particularly necessary for young and new born animals (Ravindran, 2013).

The microbes producing lipase can be found in diverse habitat like industrial wastes, vegetable oil processing factories, oil contaminated soil, oil seeds and hot springs. Lipase producing microbes constitute bacteria, fungi, yeast, and actinomyces (Wang et al., 2009). Lipase produced by bacteria with various properties and specificities have been studied and characterized. Lipase can be isolated from different bacterial species like Bacillus, Pseudomonas (Kiran et al., 2008; Wang et al., 2009).

Cold active lipases are those lipolytic enzymes which are isolated from microorganisms dwelling in cold habitats. Cold-adapted enzymes function efficiently at cold temperature with high catalytic activity as compared to mesophilic or thermophilic lipases. The cold active or psychrophilic lipases adapted structural characteristics that show a high level of flexibility, especially around the active site are translated into low activation enthalpy, low-substrate affinity and higher specific activity at low temperature range. The research work on cold active lipases is increasing at a rapid and exciting rate (Joseph et al., 2011).

Microorganism's tolerating low temperatures (near $5^{\circ} \mathrm{C}$ ) are the sources of cold active lipases. As a lot of number of lipase producing sources are existed, only a few bacteria and yeast were exploited for the generation of cold active lipolytic enzymes. From time to time many research studies have been done to check and isolate lipids from those microbes possessing high activity at low temperature. Deep-sea bacteria is another excellent source of cold active lipases, Aeromonas hydrophila is another marine bacterium proliferating at temperature range between 4 and $37^{\circ} \mathrm{C}$ can also produce cold active lipases (Kavitha, 2016).

Lipolytic enzymes are mostly consumed in lipids and oils processing. It is also used in detergents and degreasing formulations, food processing, the synthesis of fine chemicals and pharmaceuticals, paper industry, and cosmetic manufacture (Rasmey et al., 2017). It can also be used to speed up the breakdown of fatty waste and polyurethane (Andualema and Gessesse, 2012). Low temperature microorganisms can be utilized for bioremediation of polluted cold soils and wastewaters and their enzymes can have application in molecular biology, medical research, food or feed industries, detergents or cosmetics (Margesin and Feller, 2010). Based on their efficient catalytic activity at low temperature and low thermos-stability and uncommon specificity of cold active lipases suggest new opportunities for biotechnological exploitation. They are used as additional supplements in detergents, food industries, bioremediation and molecular biology applications (Cavicchioli et al., 2011; Rasmey et al., 2017). 
Currently lipases from psychrophiles are attracting enormous attention because of the reason that they have tremendous biotechnological and industrial application potential. Most of the lipolytic enzymes used in industry are of microbial origin (Singh et al., 2016). There is an increasing desire to produce feasible ways and search out optimized conditions to produce psychrophilic enzymes because they are used in detergents. It can become feasible to develop laundry applications that can be performed at lower temperature with such enzymes. For achieving such purposes psychrophilic lipases have great commercial importance.

The enzymes of produced by cold adapted microorganisms are cold active which are economically beneficial because of saving energy, minimize the need for expensive heating step, work efficiently in cold medium and during the winter season, produce enough reaction yields, accommodate a high stereospecificity, reduces unwanted chemical reactions that usually occurs at high temperature. They are also thermal labile which exhibit the property of rapid and easy inactivation when it is required (Kumar et al., 2011). The heat inactivation capabilities of cold active enzymes have special concern to the food industry where it is used to avoid any modification of heat sensitive components of food (Ray and Rosell, 2017).

On basis of rapid developments in biotechnology and industries, there is a need for new lipases with novel characteristics (Ugras and Umez, 2016). Searching for more microorganisms to produce more lipolytic enzymes will provide new ways to answer different environmental problems and to execute many synthetic reactions. The increase in interest about bacterial lipases is due the facts that they are more stable in severe conditions as compared to those isolated from other organisms. The increasing attention towards psychrophilic enzymes enables us to screen bacteria and optimize culture conditions for efficient enzymes production. Therefore, present study aims to isolate bacteria from cold habitat and its screening for lipase production, purification, characterization and phylogenetic analysis.

\section{Materials and methods}

Lipase produced by the psychrophilic bacteria Pseudomonas mandelii HTB2 isolated from Batura glacier, Hunza Valley, Pakistan, was used for the study.

\section{Qualitative and quantitative test}

Production of lipase was detected by using the mehtod, mentioned by Sierra (1957). Tween 80 (Sorbitan Monooleate) was used as a substrate. The medium used for screening purpose contained $(\mathrm{g} / \mathrm{l})$; peptone $10.0, \mathrm{NaCl} 5.0, \mathrm{CaCl}_{2} .2 \mathrm{H}_{2} \mathrm{O} 0.1$ and agar 20.0. $\mathrm{pH}$ of this medium was 7.

Tween 80 was sterilized separately by autoclaving for $20 \mathrm{~min}$ at $15 \mathrm{Ibs}$ pressure. About $1 \mathrm{ml}$ of Tween 80 was added per $100 \mathrm{ml}$ of sterilized medium and pouring was done. After solidification of media, four different cultures were inoculated. The appearance of the clear zones around the colonies indicated lipolytic activity, due to degradation of the substrate. The bacterial cultures that showed clear zones were used for further studies.

\section{Rhodamine B assay}

Rhodamine B and olive oil containing medium was also used for screening of lipase producing bacteria. Medium was composed of ( $\mathrm{ml} / \mathrm{l}$ or $\mathrm{g} / \mathrm{l})$; sucrose 1.0, yeast extract 1.0, 
peptone 2.0, $\mathrm{NH}_{4} \mathrm{SO}_{4} 1.0, \mathrm{~K}_{2} \mathrm{HPO}_{4} 1.0, \mathrm{MgSO}_{4} .7 \mathrm{H}_{2} \mathrm{O}$ 0.1, $\mathrm{FeSO}_{4} .7 \mathrm{H}_{2} \mathrm{O} 0.01$, Olive oil 3 $\mathrm{ml}$ and Rhodamine B solution $(0.1 \% \mathrm{w} / \mathrm{v}) 3 \mathrm{ml}$.

Olive oil and Rhodamine B dye containing medium was used for the screening of lipolytic enzyme. The appearance of clear zone around the culture streak indicated lipase production. The lipase positive colonies were visualized by the help of trans illuminator. For quantitative test, above mentioned liquid medium with lipase substarates was used. To analysed the activity of lipase, enzyme assay (for lipase), and estimation of protein was performed.

\section{Production and purification of lipase}

The bacterial isolate HTB2 was grown in above mentioned production media in shaking incubator for 72 hours by keeping all the optimized condition $(\mathrm{pH} 9)$ at $10^{\circ} \mathrm{C}$, temperature, in the presence of Tween-80, for maximum production of lipase, for further purufication purpose. Optimisation results have already been reported in early part of research work (Shaheen et al., 2018). The culture was centrifuged and following steps were done for lipase purification.

$>$ Separation of bacterial cells from fermentation medium.

Precipitation (Acetone precipitation and Ammonium sulphate precipitation).

$>$ Column chromatography.

\section{Separation of bacterial cells from fermentation medium}

The bacterial cells separation from fermentation medium was facilitated by centrifugation process. The enzyme production medium was centrifuged (Kokusan, Japan) for 25 minutes at $10000 \mathrm{rpm}$ at $4^{\circ} \mathrm{C}$ temperature. The supernatant obtained was stored and its lipolytic activity was determined and recorded.

\section{Acetone precipitation}

Organic solvents brought out precipitation of proteins mainly by changing the solvation of proteins with water. This reaction was carried out at low temperature to avoid denaturation due to the heat of mixing when the organic solvent is added to water. Acetone was used as solvent for precipitating proteins. The optimum amount of acetone to precipitate proteins was optimized by adding varying amount of acetone. Protein estimation and lipase assay were done with each batch of precipitation. Chilled acetone was added slowly drop wise to avoid the formation of locally high concentration of organic solvent. The solvent temperature was kept below $0^{\circ} \mathrm{C}$. The mixture was allowed to stand overnight and then centrifuged. The supernatant was decanted carefully. Residues of organic solvent can be removed from solvent by vacuum. The pellet was dissolved in minimum amount of sulphate buffer having $\mathrm{pH} 8.0$ and stored at $-20^{\circ} \mathrm{C}$ temperature and used for analytical studies.

\section{Ammonium sulphate precipitation}

Solid ammonium sulphate was added to the crude enzymes at a concentration of $60 \%$. Precipitates were collected by centrifuging the solution at $10000 \mathrm{rpm}$ for 25 minutes. The supernatant lipolytic activity was checked. If there was lipolytic activity in supernatant then again, the solution is treated with $60 \%$ ammonium sulphate for further precipitation. 


\section{Column chromatography (Sephadex G-75)}

Sephadex G-75 was used as a medium for column chromatography. It was prepared by adding $3 \mathrm{~g}$ Sephadex G-75 in $200 \mathrm{ml}$ phosphate buffer along with $0.02 \%$ sodium azide and fluconazole and incubated for 48 hours at $45^{\circ} \mathrm{C}$. Sodium azide and fluconazole were used as antimicrobial agents while incubation was required to attain the final size. Before addition to column, gel and buffers were sonicated for 1 hour. Column was cleaned by thoroughly washing with distilled water and observed for leakage. Column was filled in such a way that bubbles were not formed. The column was allowed overnight at room temperature for proper packing. Partially purified enzymes were added to the column with a flow rate of $0.30 \mathrm{ml} / \mathrm{min}$. About $3 \mathrm{ml}$ of sample was passed with the help of continuous addition of buffer and total 24 fractions were collected. Each fraction was analyzed for protein estimation by taking O.D at $280 \mathrm{~nm}$. Lipase positive fractions were combined and stored at $4^{\circ} \mathrm{C}$ for further alipase activity analysis.

\section{Lipase assay}

Activity of lipase was determined by using the following method (Lesuisse et al., 1993). A chromogenic substrate ( $p$ NPL), $p$ - nitrophenyl laurate was used. Lipase acted on $p$ NPL and break it into lauric acid and $p$-nitrophenol. Activity (in terms of unit), is defined as the quantity of enzyme that can hydrolyze $1 \mu \mathrm{l} /$ mole substrate in one minute.

\section{Protein estimation}

For calculating protein estimation, Lowry method (Lowry et al., 1951) was performed using BSA (bovine serum albumin) as standard.

\section{Characterization of purified lipases}

Purified lipases were further characterized and analyzed for factors that are known to affect their activity. Relative activity (\%) was calculated by taking the highest value as $100 \%$.

\section{Effect of temperature on lipase activity}

Purified lipase activity was observed by incubating the purified lipase at various temperatures $\left(25,30,35,40,45\right.$ and $\left.50^{\circ} \mathrm{C}\right)$ and determining the residual activity.

\section{Effect of pH on lipase activity}

The activity of purified lipase was observed at various $\mathrm{pH} ; 3.0,4.0,5.0,6.0,7.0,8.0$, 9.0, 10 and $\mathrm{pH} 11$ and determining the residual activity.

\section{Molecular identification}

\section{DNA extraction, PCR amplification and sequencing}

Thermoscientific DNA extraction kit was used to extract the DNA of HTB2 isolate. The extraction protocol was used as given by Thermoscientific company.16S rRNA gene was amplified by using a set of universal primers i.e. 27F (5'- AGA GTT TGA TYM TGG CTC AG-3') and 1492R (5'-TAC CTT GTT AYG ACT T-3'). Optimized conditions of PCR were as; initial denaturing at $94^{\circ} \mathrm{C}$ for 5 min followed by 35 cycles, each cycle consisted of denaturing for 30 seconds at $94^{\circ} \mathrm{C}$, primers annealing for 30 seconds at $54^{\circ} \mathrm{C}$, 
extension for 30 seconds at $72^{\circ} \mathrm{C}$, followed by final extension of 10 minutes at $72^{\circ} \mathrm{C}$. These steps were followed by infinite hold at $4^{\circ} \mathrm{C}$ until PCR product was collected. PCR product was run along with DNA ladder sequence on agarose gel to confirm the size of our PCR product. Amplified PCR product was sent to Macrogen Inc. Korea for sequencing purpose. The quality of obtained sequence was analyzed by using BioEdit and Chromas elite software. The good quality sequences were selected for BLAST search, homology and phylogenetic analysis.

\section{Identification and phylogenetic analysis}

The selected sequences were used for homology search in National Centre for Biotechnology (NCBI) data base to find out the identity of the study isolates. For phylogenetic analysis sequences were obtained from NCBI. MEGA 6 software was used to construct the phylogenetic tree.

Overall the study deals with the partial purification of lipase produced by a psychrophilic bacteria Pseudomonas mandelii HTB2 by acetone precipitation and gel permeation chromatography, and checked its activity at varying temperatures and $\mathrm{pH}$ values. The experiments were run in triplicates. All the standard methodologies were followed for analysis and enzyme assays.

\section{Results}

\section{Qualitative tests}

Based on qualitative analysis, the HTB2 isolate was found effective producer of lipase among the four isolates. The formation of zone around the colonies indicated the lipases production (Fig. 1).

\section{Rhodamine B plate assay}

The lipase production from HTB2 isolate was further verified by using both (Rhodamine B), and (olive oil), in agar media. Transilluminator was used to visualize HTB2 and the fluorescence indicated the lipase activity (Fig. 1).

Previously reported (Shaheen et al., 2018) optimum growth conditions for the production of lipase $\left(7.6\right.$ and $25.9 \mathrm{U} / \mathrm{mg}$ ) by the same strain $\mathrm{HTB} 2$ at $10^{\circ} \mathrm{C}$, after 72 hours of incubation, respectively, and Tween 80 was best among different substrates, for lipase production $(20.8 \mathrm{U} / \mathrm{mg})$, in liquid medium with $\mathrm{pH} 9$, at $10^{\circ} \mathrm{C}$. Glucose $(19.4 \mathrm{U} / \mathrm{mg})$ and casein $(15.5 \mathrm{U} / \mathrm{mg}$ ), were found good additional sources (carbon and nitrogen), in the enhancement of production of lipase. These conditions were applied here for production of lipase and then subjected to purification.

\section{Purification of lipase}

\section{Acetone precipitation}

Different concentrations of Acetone were added to already centrifuge fermentation medium or cell free supernatant which highly affected the precipitation. The concentration of precipitated lipase enhanced until $90 \%$ of acetone. Any further addition of acetone caused decrease in the concentration of enzyme. 


\section{Ammonium sulphate precipitation}

The result of ammonium sulphate precipitation showed poor yield of lipase.

\section{Column chromatography}

The precipitated enzymes were subjected to column chromatography using Sephadex G 75-120. Maximum activity was found among fractions $5-7$ and $12-16$, while highest specific activity was observed in fractions 7 and 15 with activity of 9.11 and $9.77 \mathrm{U} / \mathrm{ml}$, respectively (Fig. 2).
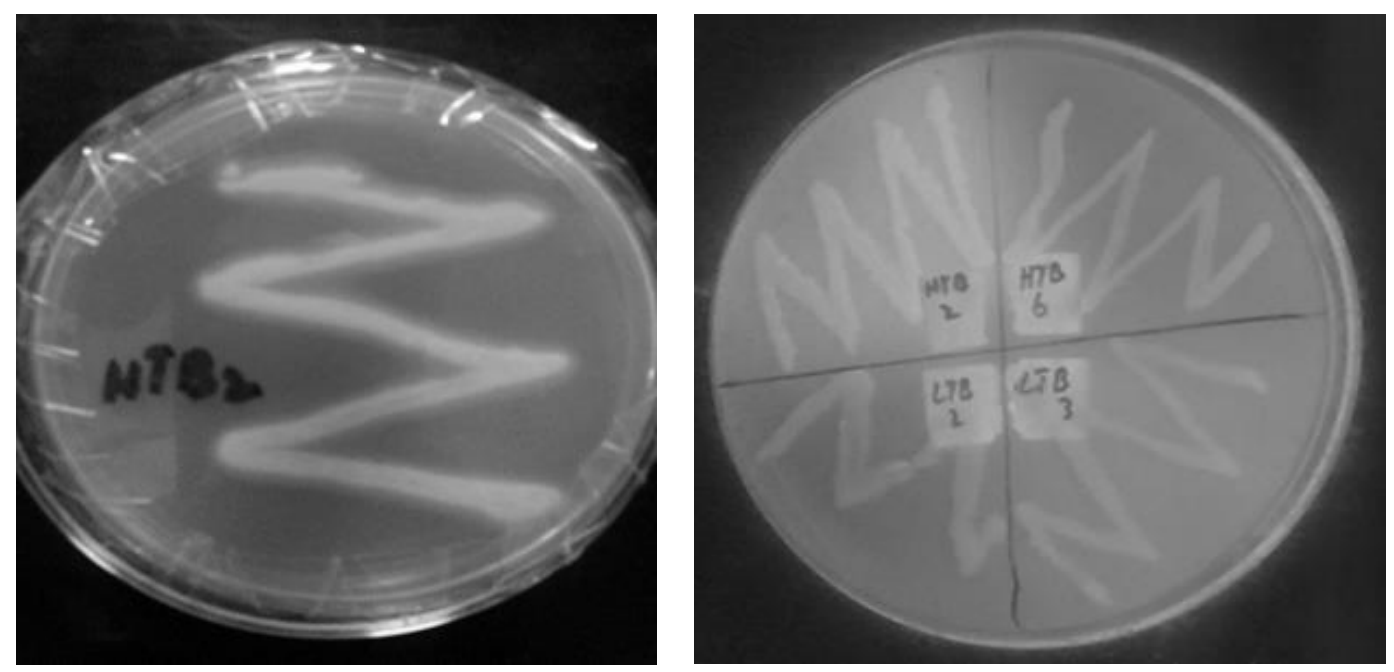

Figure 1. Rhodamine B plate assay of isolate $H T B 2$ at $10^{\circ} \mathrm{C}$ after 72 hours of incubation

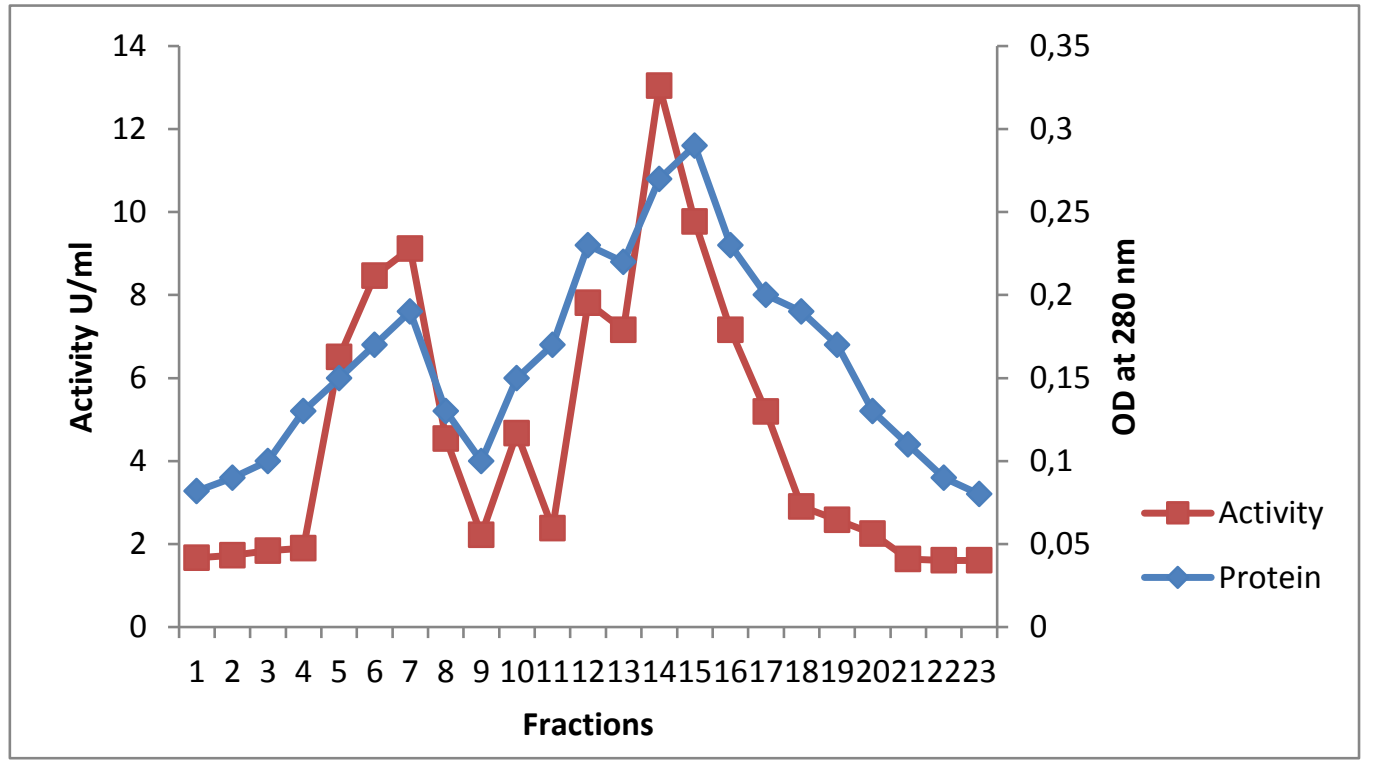

Figure 2. Profile of lipases from Pseudomonas mandelii HTB2 after filtration of Sephadex $G$ 75-120 chromatography. The two peaks of lipase activity in the graph indicated multiple forms of enzyme 


\section{Characterization of lipases}

\section{Effect of temperature on the purified lipases}

The activity of lipase after purification was also analyzed at various temperatures, ranges from $25-50^{\circ} \mathrm{C}$ and maximum specific activity was found at $45^{\circ} \mathrm{C}$ (Fig. 3). The lipases showed $80 \%$ and $50 \%$ initial activity at 50 and $35^{\circ} \mathrm{C}$, respectively.

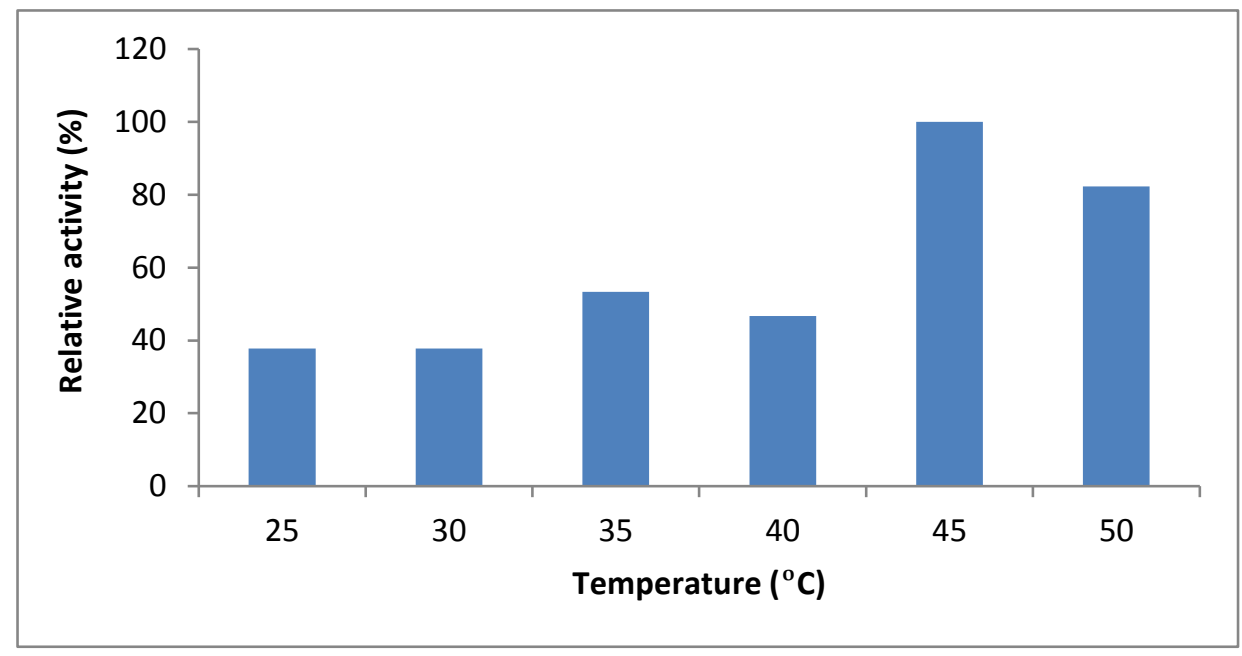

Figure 3. Effect of temperature on purified lipase activity

\section{Effect of $p H$ on purified lipases}

The activity of purified lipases was evaluated at various $\mathrm{pH}$ on optimum temperature $\left(45^{\circ} \mathrm{C}\right)$. The lipases were highly active at $\mathrm{pH} 10$ while showed activity at a wide $\mathrm{pH}$ range (Fig. 4). More than $75 \%$ activity was found at $\mathrm{pH} 9.0$ and 11.0 .

\section{Molecular identification and phylogenetic analysis}

Sequencing of DNA product showed that HTB 2 belonged to different taxonomic groups. Similarity index of HTB 2 with other isolates is shown in Table 1. Evolutionary relationship of HTB 2 is shown in Fig. 5.

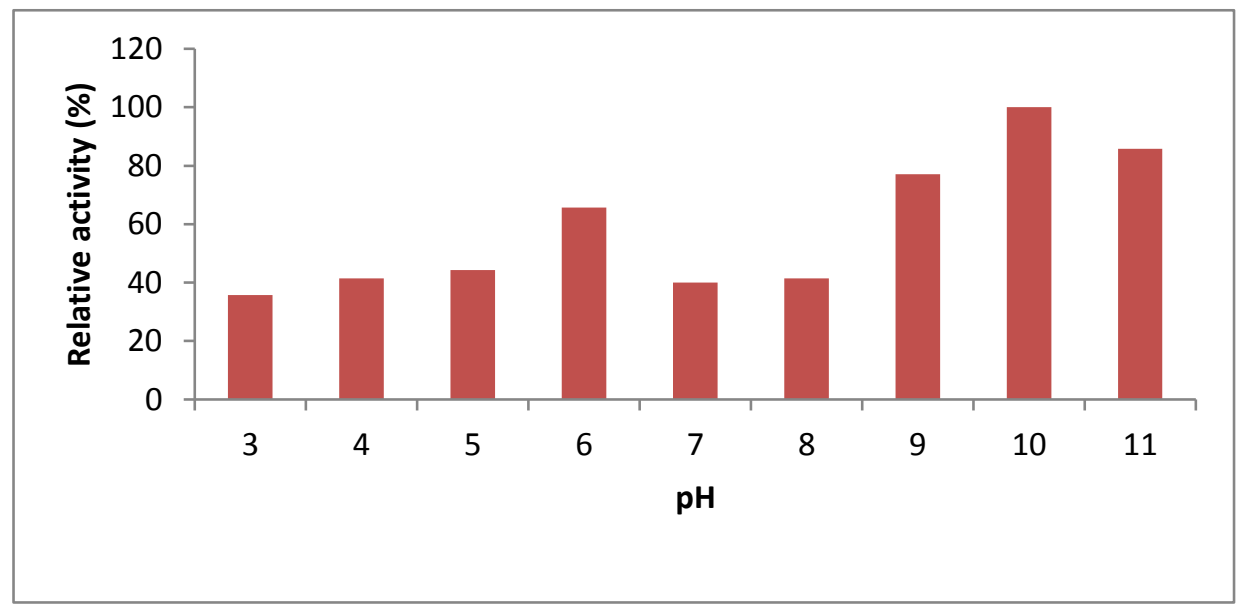

Figure 4. Effect of $p H$ on purified lipase activity 
Table 1. Phylogenetic analysis of HTB 2

\begin{tabular}{c|c|c}
\hline Isolate & Homologous sp. & Identity (\%) \\
\hline & Pseudomonas mandelii & 100 \\
HTB 2 & Shewanella sp. & 97 \\
& Halomonas sp. & 97 \\
& Pectobacterium carotovorum & 97 \\
\hline
\end{tabular}
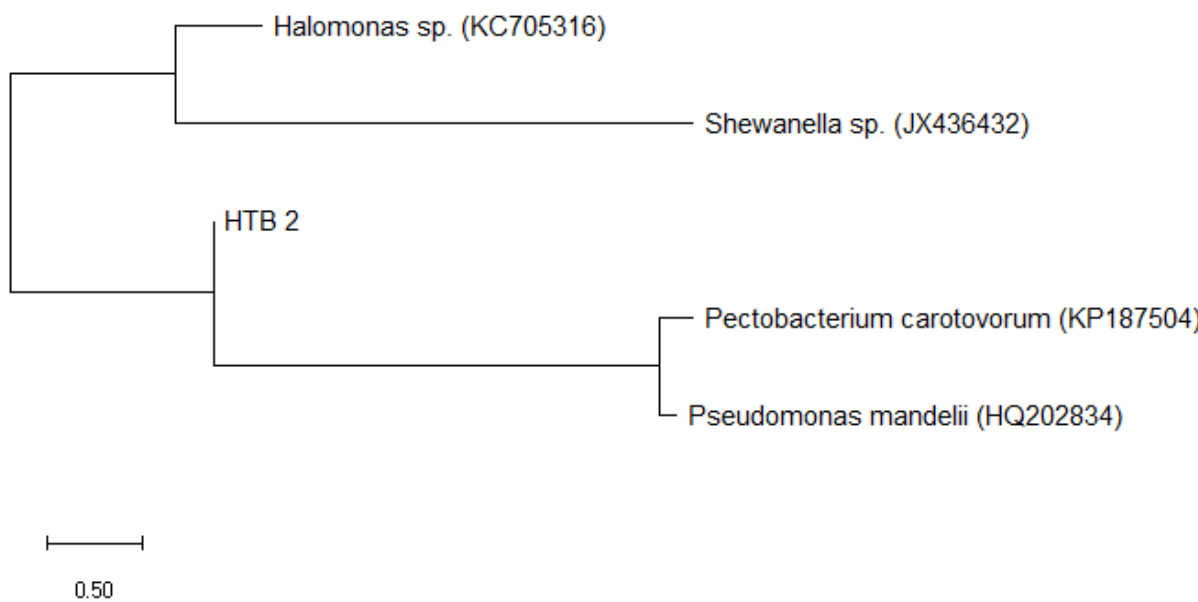

Figure 5. Phylogenetic relation of the HTB 2 with the isolates obtained from NCBI

\section{Discussion}

Microorganisms thrive in cold environment. Psychrophilic and psychrotrophic microbes have the ability to generate cold active enzymes that have potential application in industries. Furthermore, high enzymatic activity at reduced temperature and thermal stability are the important factors which make these enzymes 'cold adapted'. By virtue of these unique characteristics, lipases are key products of rapidly growing biotechnology industry (Kavitha, 2016). Moreover, understanding the whole structure of proteins is necessarily required to point out the link between the structure and function of proteins (Singh et al., 2016).

In the past decades the attention towards microbial cold active enzymes has been increased. This is due to the reason that they are highly specific and economically advantageous without any ecological impact. Use of these enzymes instead of harsh conditions and harsh chemicals, is helpful to conserve energy and avoid pollution. As these enzymes are substrate specific thus prevent production of unwanted byproducts so avoiding extensive downstream processing. When immobilized, these enzymes can be reused several times (Robinson, 2015).

Many potential producers including bacteria, yeast and fungi have been studied for lipase production through techniques of fermentation. Extracellular lipase was isolated from various bacterial species like Pseudomonas (Ertuğrul et al., 2007; Kiran et al., 2008; Wang et al., 2009).

Bacterial isolate HTB2, previously recovered from Batura glacier (Pakistan) in Applied Environmental and Geomicrobiology Laboratory, Department of Microbiology, Quaid-i-Azam University Islamabad, is identified in the current study as Pseudomonas mandelii HTB2. Very few researchers have reported this species from low temperature 
environment. Pseudomonas is generally of very diverse nature and ubiquitous in nature and are also known to produce a number of metabolites and produce biofilm as well. Pseudomonas mandelii is a fluorescent, Gram negative, rod-shaped bacterium reported to occur in natural mineral waters (Jang et al., 2012) and agricultural fields (Dandie et al., 2007). $P$. mandelii is nonhalophilic and thrives at low temperatures and produces extracellular enzymes (Gratia et al., 2009).

Li et al. (2013) have reported $a$ novel facultative psychrotroph Pseudomonas mandelii strain CBS-1 from soil of Changbai Mountain, China, that accumulated poly- $\beta$ hydroxybutyrate (PHB). Another novel strain of Pseudomonas mandelii isolated from Antarctica was found to produce high concentrations of alginate (Vásquez-Ponce et al., 2017). Psychrotolerant Pseudomonas mandelii SR1 synthesized the small sized silver nanoparticles (AgNPs) at $12^{\circ} \mathrm{C}$, and showed larvicidal activity, against Anopheles subpictus and Culex tritaeniorhynchus larvae, thus can be used control of larvae in waters in cold environments (Mageswari et al., 2015).

Lipase produced by Pseudomonas mandelii HTB2 was purified and characterized on basis of activity at different $\mathrm{pH}$ and temperature. The purified lipase showed optimum activity at $45^{\circ} \mathrm{C}$. Every enzyme has a specific $\mathrm{pH}$ at which works most efficiently called optimum $\mathrm{pH}$. This phenomenon is due to the exact arrangement of the active site of an enzyme occupied by hydrogen and ionic bond to some extent (between $-\mathrm{NH}_{2}$ and $-\mathrm{COOH}$ groups). Even small amount of change in $\mathrm{pH}$ alter this bonding which causes conformational changes in the active site which then become unable to attach with the substrate. The Pseudomonas mandelii HTB2 showed maximum residual activity at $\mathrm{pH} 10$. On basis of these unique properties of enzyme from $P$. mandelii HTB2 showing activity at higher temperature and alkaline $\mathrm{pH}$, can have a number of applications in industry as well as environment. Residual activity of psychrotrophic lipase from Acinetobacter sp. $\mathrm{O} 16$ to be optimum at $40^{\circ} \mathrm{C}$, while optimal activity was observed at $35^{\circ} \mathrm{C}$ and $\mathrm{pH} 7.5$ (Sahay and Chouhan, 2018), while that from Acinetobacter sp. SY-01 lipolytic activity was optimum at $50^{\circ} \mathrm{C}$ and $\mathrm{pH} 10$ (Han et al., 2003) with potential application in detergent industry (Wang et al., 2012). In another study performed by Yuan et al. (2010), lipase retained $80.7 \%$ of its activity at $40^{\circ} \mathrm{C}$. Acinetobacter sp. XMZ-26 was isolated from soil samples obtained from glaciers in Xinjiang Province, China. Maximal lipase activity was observed at $15^{\circ} \mathrm{C}$ and $\mathrm{pH} 10$. Purified lipase was active between $5^{\circ} \mathrm{C}$ and $35^{\circ} \mathrm{C}$ (Zheng et al., 2011). Most of the lipases isolated from Burkhulderia origin showed residual activity in the range pH 3 to 10.5 (Yuan et al., 2010). The lipases from psychotrophic Serratia marcescens was characterized, the optimum $\mathrm{pH}$ was between 8 and 9 (Abdou, 2003).

\section{Conclusions}

This study investigated the lipase screening qualitatively and quantitatively from cold adapted Pseudomonas mandelii HTB2, lipase purification was carried out by using acetone and ammonium sulphate precipitation and column chromatography methods. Stability of semi-purified lipase was analysed at various range of temperature and $\mathrm{pH}$, in the presence of different substrates. We conclude that further characterization related to combined effect of different factors is needed with respect to lipase production and its stability. Present study would provide basis for investigation of other industrially important enzyme producing bacteria from this habitat. 


\section{REFERENCES}

[1] Andualema, B., Gessesse, A. (2012): Microbial lipases and their industrial applications. Biotechnology 11: 100-118.

[2] Åqvist, J., Isaksen, G. V., Brandsdal, B. O. (2017): Computation of enzyme cold adaptation. - Nature Reviews Chemistry 1: 0051.

[3] Cavicchioli, R., Charlton, T., Ertan, H., Omar, S. M., Siddiqui, K. S., Williams, T. J. (2011): Biotechnological uses of enzymes from psychrophiles. - Microbial Biotechnology 4: 449-460.

[4] Dandie, C. E., Burton, D. L., Zebarth, B. J., Trevors, J. T., Goyer, C. (2007): Analysis of denitrification genes and comparison of nosZ, cnorB and $16 \mathrm{~S}$ rDNA from culturable denitrifying bacteria in potato cropping systems. - Systematic and applied microbiology 30: 128-138.

[5] Ertuğrul, S., Dönmez, G., Takaç, S. (2007): Isolation of lipase producing Bacillus sp. from olive mill wastewater and improving its enzyme activity. - Journal of Hazardous Materials 149: 720-724.

[6] Gratia, E., Weekers, F., Margesin, R., D’Amico, S., Thonart, P., Feller, G. (2009): Selection of a cold-adapted bacterium for bioremediation of wastewater at low temperatures. Extremophiles 13: 763-768.

[7] Han, S. J., Back, J. H., Yoon, M. Y., Shin, P. K., Cheong, C. S., Sung, M. H., Hong, S. P., Chung, I. Y., Han, Y. S. (2003): Expression and characterization of a novel enantioselective lipase from Acinetobacter species SY-01. - Biochimie 85: 501-510.

[8] Jang, S. H., Kim, J., Kim, J., Hong, S., Lee, C. (2012): Genome sequence of cold-adapted Pseudomonas mandelii strain JR-1. - Journal of bacteriology 194: 3263-3263.

[9] Joseph, B., Upadhyaya, S., Ramteke, P. (2011): Production of cold-active bacterial lipases through semisolid state fermentation using oil cakes. - Enzyme Research, 2011.

[10] Kavitha, M. (2016): Cold active lipases-an update. - Frontiers in Life Science 9: 226-238.

[11] Kiran, G. S., Shanmughapriya, S., Jayalakshmi, J., Selvin, J., Gandhimathi, R., Sivaramakrishnan, S., Arunkumar, M., Thangavelu, T., Natarajaseenivasan, K. (2008): Optimization of extracellular psychrophilic alkaline lipase produced by marine Pseudomonas sp.(MSI057). - Bioprocess and Biosystems Engineering 31: 483-492.

[12] Kumar, L., Awasthi, G., Singh, B. (2011): Extremophiles: a novel source of industrially important enzymes. - Biotechnology 10: 121-135.

[13] Lesuisse, E., Schanck, K., Colson, C. (1993): Purification and preliminary characterization of the extracellular lipase of Bacillus subtilis 168, an extremely basic pH-tolerant enzyme. - European Journal of Biochemistry 216: 155-160.

[14] Mageswari, A., Subramanian, P., Ravindran, V., Yesodharan, S., Bagavan, A., Rahuman, A. A., Karthikeyan, S., Gothandam, K. M. (2015): Synthesis and larvicidal activity of lowtemperature stable silver nanoparticles from psychrotolerant Pseudomonas mandelii. Environmental Science and Pollution Research 22: 5383-5394.

[15] Margesin, R., Feller, G. (2010): Biotechnological applications of psychrophiles. Environmental Technology 31: 835-844.

[16] Pulicherla, K. K., Ghosh, M., Kumar, P. S., Sambasiva Rao, K. R. S. (2011): Psychrozymes-the next generation industrial enzymes. - Journal of Marine Science: Research and Development 1: 1-7.

[17] Rasmey, A. H. M., Aboseidah, A. A., Gaber, S., Mahran, F. (2017): Characterization and optimization of lipase activity produced by Pseudomonas monteilli 2403-KY120354 isolated from ground beef. - African Journal of Biotechnology 16: 96-105.

[18] Ravindran, V. (2013): Feed enzymes: The science, practice, and metabolic realities. Journal of Applied Poultry Research 22: 628-636.

[19] Ray, A. (2012): Application of lipase in industry. - Asian Journal of Pharmacy and Technology 2: 33-37. 
[20] Ray, R. C., Rosell, C. M. (2017): Lipase: Properties, Functions and Food Applications. Microbial Enzyme Technology in Food Applications (pp. 228-254). CRC Press.

[21] Renge, V. C., Khedkar, S. V., Nandurkar, N. R. (2012): Enzyme synthesis by fermentation method: a review. - Chemical Society Reviews 2: 585e90.

[22] Robinson, P. K. (2015): Enzymes: principles and biotechnological applications. - Essays in Biochemistry 59: 1-41.

[23] Sahay, H., Babu, B. K., Singh, S., Kaushik, R., Saxena, A. K., Arora, D. K. (2013): Coldactive hydrolases producing bacteria from two different sub-glacial Himalayan lakes. Journal of Basic Microbiology 53: 703-714.

[24] Shaheen, M., Ullah, I., Rafiq, M., Rehman, M. M., Hasan, F. (2018): Influence of physicochemical conditions on the production of lipase by Psychrophilic Bacteria Isolated from Batura Glacier, Hunza Valley, Pakistan. - International Journal of Biosciences 12: 111.

[25] Sierra, G. (1957): A simple method for the detection of lipolytic activity of microorganisms and some observations on the influence of the contact between cells and fatty substrates. - Antonie van Leeuwenhoek 23: 15-22.

[26] Singh, R., Kumar, M., Mittal, A., Mehta, P. K. (2016): Microbial enzymes: industrial progress in 21st century. - 3 Biotechnology 6: 174.

[27] Smaniotto, A., Skovronski, A., Rigo, E., Tsai, S. M., Durrer, A., Foltran, L. L., Paroul, N., Luccio, M. D., Oliveira, J. V., Oliveira, D. D., Treichel, H. (2014): Concentration, characterization and application of lipases from Sporidiobolus pararoseus strain. Brazilian Journal of Microbiology 45: 294-301.

[28] Szilveszter, Sz., Raduly, B., Miklóssy, I., Ábrahám, B., Lanyi, Sz., Nicolae, D. R. (2009): Enzymatic activity studies of biological wastewater treatment. - Universitatis BabesBolyai, p.113.

[29] Ugras, S., Uzmez, S. (2016): Characterization of a newly identified lipase from a lipaseproducing bacterium. - Frontiers in Biology 11: 323-330.

[30] Vasquez-Ponce, F., Higuera-Llantén, S., Pavlov, M. S., Ramírez-Orellana, R., Marshall, S. H., Olivares-Pacheco, J. (2017): Alginate overproduction and biofilm formation by psychrotolerant Pseudomonas mandelii depend on temperature in Antarctic marine sediments. - Electronic Journal of Biotechnology 28: 27-34.

[31] Wang, S. L., Lin, Y. T., Liang, T. W., Chio, S. H., Ming, L. J., Wu, P. C. (2009): Purification and characterization of extracellular lipases from Pseudomonas monteilii TKU009 by the use of soybeans as the substrate. - Journal of Industrial Microbiology and Biotechnology 36: 65-73.

[32] Wang, H., Zhong, S., Ma, H., Zhang, J., Qi, W. (2012): Screening and characterization of a novel alkaline lipase from Acinetobacter calcoaceticus 1-7 isolated from Bohai bay in China for detergent formulation. - Brazilian Journal of Microbiology 43: 148-156.

[33] Yuan, B., Cai, Y., Liao, X., Yun, L., Zhang, F., Zhang, D. (2010): Isolation and identification of a cold-adapted lipase producing strain from decayed seeds of Ginkgo biloba L. and characterization of the lipase. - African Journal of Biotechnology 9: 26612667.

[34] Zheng, X., Chu, X., Zhang, W., Wu, N., Fan, Y. (2011): A novel cold-adapted lipase from Acinetobacter sp. XMZ-26: Gene cloning and characterisation. - Applied Microbiology and Biotechnology 90: 971-980. 